\title{
EMOTIONAL STATE AND INEQUALITY AMONG LITHUANIAN EMIGRANTS
}

\author{
Dainius Genys \\ Andrei Sakharov Research Centre for Democratic Development \\ Vytautas Magnus University, Kaunas, Lithuania \\ Email:dainius.genys@vdu.lt
}

\section{Ilona Strumickienè}

Adolfas Damušis Democratic Studies Centre

Martynas Mažvydas National Library of Lithuania, Vilnius, Lithuania

Email: ilona.strumickiene@lnb.lt

\section{Ričardas Krikštolaitis}

Department of Mathematics and Statistics

Vytautas Magnus University, Kaunas, Lithuania

Email: ricardas.krikstolaitis@vdu.lt

\begin{abstract}
Recent public polls have revealed that 56.7 percent of Lithuanian emigrants $(\mathrm{N}=1500)$ feel superfluous in their homeland. Many of them are not only disappointed with the country and therefore decide to leave, but also can find neither adequate emotional relations with their homeland afterwards nor maintain healthy emotional ties with fellow Lithuanians. With this in mind, the article aims to describe the contexts that determine the emotional state of Lithuanian emigrants and the distribution of emotional inequality among the most prominent social groups. The survey was conducted in order to test the emotional state of Lithuanian emigrants and gather empirical evidence regarding the specific reasons for that. Accordingly, three tasks are formulated for this empirical research: to perform a cluster analysis and distinguish the main social groups based on socioeconomic differences in society; to identify and describe contexts that lead to a poor emotional state (contexts of interactions) and a subjective reflexivity of the public; to explore the differences of emotional inequality among the researched groups. The article concludes with three intertwined factors that foster the poor emotional state of emigrating Lithuanians. The survey was conducted from January to February 2018 (number of respondents - N=1500).
\end{abstract}

Keywords: cluster analysis, emigration, emotions, inequality, Lithuania 


\section{INTRODUCTION}

Despite the improving macroeconomic indicators of the country, the proportion of emigration from Lithuania remains high. In comparison to countries with similar economic development, emigration rates from Lithuania are the highest in the region (Emigration issues 2006; Statistical data 2018; Statistical data 2019). It is not surprising that contemporary migration receives appropriate attention in Lithuania (Servetkienè 2012; Woolfson \& Juska \& Genelyte 2012; Laurinavičius \& Laurinavičius 2017; Genys \& Krikštolaitis 2018; Genelytė 2019). It seems that emigration is determined not only by economic factors but also by deeper, more complex causes related to more general socio-political and socio-cultural microclimate within society, especially its emotional capital.

Recent public polls have revealed that 56.7 percent of Lithuanian emigrants $(\mathrm{N}=1500)$ feel superfluous in their homeland. Many of them are not only disappointed with the country and therefore decide to leave, but also can find neither adequate emotional relations with their homeland afterwards nor maintain healthy emotional ties with fellow Lithuanians. As we know from the previous studies, a poor emotional state and inability to experience positive emotions have social consequences (Bourdieu et al. 1999: 421). The groups that feel emotionally excluded from society assume that their hopes and expectations are unrealistic, leading them to hopelessness. Ignoring the emotional dimension carries the risk of not realizing the experience of being on the margins of social life and the pain people experience. With this in mind, the article aims to describe the contexts that determine the emotional state of Lithuanian emigrants and the distribution of emotional inequality among the most prominent social groups.

To research emotions and their distribution in society, especially in societies that have undergone major transformations over a short period (as in Lithuania), is important for several reasons. For several post-communist decades, the country's progress was associated with reforming and modernizing its political and social system (mostly institutions) in the hope that a new type of person would emerge as a result of the newly redesigned order. The accomplishments and the progress achieved over the short period is indeed impressive, but the emotional climate in society has not changed significantly. In contemporary Lithuania it is believed that political order can solve all personal problems, as well as the emotional state of society. Meanwhile, public emotions, especially when uncontrolled, can develop in several directions. The natural development of emotions through creating a controlled and attentive environment for the public to speak out can contribute to a greater civic engagement in the development of public well-being, or a kind of 'reconciliation' therapy (Lively 2017). Social change activists and professional therapists use people's emotions 
to change their self-perceptions beyond existing stereotypes and to improve their well-being. For example, overcoming low self-esteem or even inferiority complexes lets people escape from the socio-cultural and economic deprivation circle. Thus, emotions can become a powerful engine of social change, or at least their expression can serve as a kind of therapy for society. Emigrants, by speaking more boldly and systematically about their experiences and emotions, can broaden the field of discussion and encourage the public to express their emotions and their formation contexts. In other words, by raising emotional values and embedding them into the public discourse as key aspects of public life, one can expect a tangible breakthrough in shifting public attitude towards emigration, as well as a deeper public reflexivity in articulating emotional states.

The article consists of four chapters. The first one specifies various contextual preconditions for the emotional peculiarities concerning the transitional period of the country. It also reviews a few studies and draws a hypothesis on this basis. The second one is dedicated to methodology, explaining the principles of cluster formation, and identifying their main characteristics. The third one provides empirical evidence on the relationship between the attitude towards trust, expectations for the government, and civic activity among clusters. The fourth chapter demonstrates the distribution of emotional inequality among clusters.

\section{CONTEXTUAL PRECONDITIONS FOR THE PECULIARITIES OF EMOTIONS}

Four decades of research tradition in the sociology of emotions have clearly shown that emotions, from their origin to their consequences, influence and, in turn, are influenced by the social contexts in which they circulate. Sociologists agree that emotional experience depends on the meanings that individuals attribute to interaction (Thoits 1989; Stets \& Turner 2006). The nature of emotions depends on the extent to which our expectations are (or are not) justified and met during each interaction. These expectations typically relate to how we expect to be identified and accepted by others and how they behave towards us. Emotions are formed during social interactions that are influenced by certain social circumstances.

Emotions occupy an important place in everyone's life; thus, the growing attention given to this branch of sociology is not surprising (Bericat 2016). Sociological analysis of emotions can be characterized by the sociologization of emotions, i.e., they are not treated as sensory or psychological aspects of an individual, but rather as social facts. It is worth mentioning that the sociology 
of emotions in Lithuania is just beginning to take shape and there are only a few works dedicated to this field (Tereškinas \& Žilys 2013; Tereškinas 2014; Bleizgienè 2015; Noreika 2016).

Scientists discuss how many emotions there are and what are the main ones. The most common ones are anger, fear, sadness, and joy, but often surprise, disgust, and hope are also added (Turner 2000). These basic emotions are universally recognizable, but very rarely we feel emotions alone and never as disconnected from the social context, so when intertwined, they begin to reinforce and interact with each other, and this has culturally defined social implications. It is opined that confidence and joy often lead to optimism, but sadness, mistrust, and anger lead to revenge (Turner 2009: 342). Sociologists, when reading certain sets of emotions, try to find out the causes and social consequences of those emotions. By analyzing the sentiments expressed by emigrants and their emotions, we can gain a deeper understanding of certain social contexts in which certain emotions are born or formed.

Pierre Bourdieu (Bourdieu et al. 1999: 242) has warned that ignoring the emotional dimension carries the risk of not realizing the experience of being on the margins of social life and the pain people feel. When the public does not trust the authorities and personally feels their hostility (whether experienced or imagined), not only negative emotions are formed, but also hostile behavior is born, which in this case is the decision to emigrate.

Sociological research shows that emotions, as if a form of screens, depict emotional dynamics - successes and failures, ups and downs during interactions, and allow the subjects to learn about interaction partners before any actual conscious exchange of information is made (Thoits 1989: 317-318; Turner 2009: 350). For example, a government that fails to provide reasons of rejoicing for the public risks to redraw the society from itself. After analyzing the relationship between emotions and social hierarchy, researchers conclude that people's emotions, such as dissatisfaction or frustration with their country, are related to their social status. Given that differences of the position in the social hierarchy of people and the corresponding accumulation of emotional pressures are increasing, the likelihood of miscommunication rises (Kraus 2017), so it is important to analyze to what extent this is specific to Lithuania and whether and what emotional inequality exists among different social groups.

Speaking of the rather poor emotional state of Lithuanian society, sociologist Artūras Tereškinas (2014) has noted the negative emotional capital of his compatriots, which hinders the enjoyment of life. Instead, anger, rage, sadness, and frustration dominate society. No less problematic, says historian Egidijus Aleksandravičius (2019), is that we are too sympathetic to the role of victim, as if everyone around owes us something, but we do not. The reduced 
auto-reflection allows to grieve regarding others' insensitivity to our pain and misery, but does not allow to raise the question about what I do myself, and for what I am responsible.

Teodora Gaidyte speaks about the ambivalent relationship between the post-communist government and societies. On the one hand, after the collapse of the communist system, the establishment of neoliberal democracies here is not the result of a natural political system evolvement; on the other hand, as a consequence of the communist legacy, institutionalized expectations towards the government still exist in a part of society. Paradoxically enough, neither of these notions encourage active participation in political or civic activity or governmental control processes (Gaidytè 2013: 5). The relationship between the government and society in the post-Soviet space is indeed complicated (Howard 2003; Müller 2006; Spurga 2008). Even though the study on civic power in Lithuania reveals the stabilization of the citizens' power, the overall index remains relatively low, indicating an increase in the power of other sectors of society with the government in the lead (Civic Power 2016). As recent research shows, the spread of power, its penetration into the private sphere, manifests itself in its dominance in the rules and restrictions on civil liberties and choices (Gregg 2018; Genys 2018). The reduced perception of individuals' role in the country - perceiving themselves only as an object of the government, but not as a subject - also leads to the deprivation of positive emotions, which opens the way to negative ones.

In a democratic society, to criticize, disapprove or disagree with the government on its concrete decisions is a usual thing (Bermeo 2000; Howard 2003). Lithuania has achieved a certain living standard, has established a democratic system with a clear division of roles, and implemented a social welfare model allowing seemingly normal lives; some people may be doing better, others less well, but as this study demonstrates, some respondents feel constant anxiety. Previous research indicates that many emigrants, in addition to economic reasons, referred to hopelessness and desperation as the reasons for their decision to emigrate (Genys 2019). Their experiences reveal that the prevailing social system fosters anxiety. Attention is drawn to the articulation of emotions: abstract speaking, extreme examples, generalization by merging different authorities and responsibilities, but most importantly, complete despair and disability to notice good deeds. If the emotions lack critical reflexivity and rational contemplation, it may result in anger, which eventually will seek certain addressees as if they were to be blamed (despite the actual role of the addressee). In such cases, sparkling emotions can dominate rational considerations and may cloud both adequate judgment and personal responsibilities. 
Before going into details in exploring the peculiarities of the emotional state among different groups of Lithuanian emigrants, a few tendencies could be drawn from the general results. It is worth mentioning that the initial idea of the research was to investigate the noneconomic reasons of emigrations; thus, an additional block of the questionnaire was dedicated to targeting the state and the role of emotions in people's choices. Here are some of the results:

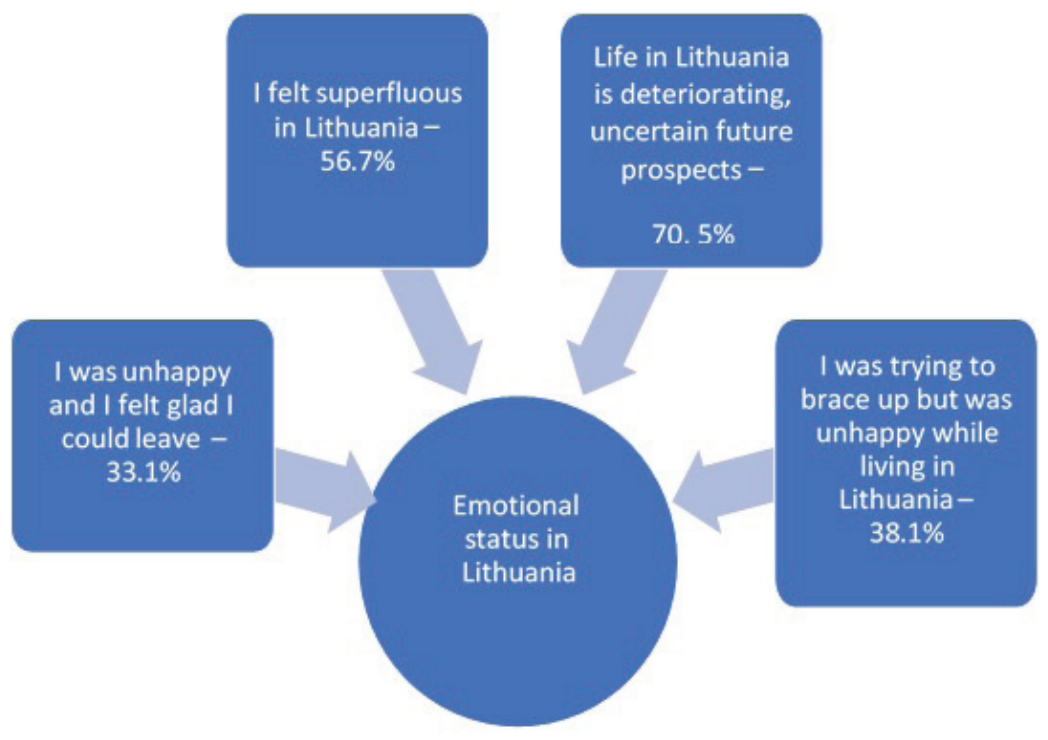

Figure 1. Emotional status in Lithuania in $2018(N=1500)$.

The overall picture illustrates the poor emotional climate: almost one-third of those who departed felt unhappy and were glad to leave; slightly more than a half did not feel needed in Lithuania; 38.1 percent just failed to be happy, and perhaps the most shocking is the fact that as many as 70.5 percent were unable to see any future perspectives in their homeland.

Feeling unhappy, and superfluous, reinforces a poor emotional state, contributes to the decision to emigrate, and leads to a further disconnection of emigrants with their homeland. The experiences of the respondents testify to people's unhappiness, but also reflect the unwell feeling. These people may have become (or at least feel that way) what they were unwilling to be (or at least do not want to be), which affects public attitudes towards them and puts a burden of society's expectations on them. It contributes to the reasons to leave the country and to move elsewhere in the hope of better emotional comfort, or perhaps the opportunity to rebuild one's life. 
A high percentage of respondents chose the answers "unhappy" or "not needed", which makes one wonder what factors in political, social, and economic life determine such a feeling and how it influences a person's decision to leave Lithuania. Negative emotions felt by those who depart are not only a sign of growing alienation in society, mistrust, and hostility towards the government but, most importantly, a reflection of grieving. The negative emotional state expressed by emigrating people stops the process of knitting society as a unified social fabric and encourages a deeper investigation of both the contexts that lead to the poor emotional state and the distribution of emotional inequality among different social groups. Based on the previous researches, three tasks are formulated for this empirical study:

- To perform a cluster analysis and distinguish the main social groups, based on socioeconomic differences in society (empirical description of the most specific socio-demographic characteristics of clusters);

- To identify and describe contexts that lead to a poor emotional state (contexts of interactions) and subjective reflexivity of the public (empirical verification of the relationship between attitudes to the government, civic engagement, and emotional state);

- To explore the differences of emotional inequality among groups (empirical description of the distribution of emotions among clusters).

\section{METHODOLOGY AND DESCRIPTION OF CLUSTERS}

The survey was conducted from January to February 2018 (N=1500). The respondents were migrants from Lithuania, starting from the age of 18, who had lived more than six months in one of these three regions in Europe - Scandinavia (500), Great Britain (500), and Southern Europe (500). Data were collected by personal public space intercept survey and via e-mail. In search of respondents, foreign Lithuanian communities and authoritative community leaders, as well as various communities' Facebook pages, were approached by the interviewers from the public opinion and market research company Vilmorus to find migrant contacts. Also, some interviews were carried out at Vilnius and Kaunas airports. The questionnaire consisted of 96 questions. It is likely that due to a large number of questions, some of the survey participants did not answer all the questions, so for some questions, the answers available are not 1500 but 1493. It is assumed that the sample has a probabilistic statistical error of 2.6 percent and a reliability of 95 percent. 
After the evaluation of the general results of the study, it was decided to perform a cluster analysis for a better understanding of the existing differences in attitudes between different social groups. The formation of the clusters was based on the notion of socioeconomic status, derived from the American tradition of social stratification research (Ganzeboom \& De Graaf \& Treiman 1992). The concept of socioeconomic status is based on three variables: education, income, and employment. Three empirical questions were formulated accordingly: What is your education? What are your main activities? What is your income?

These questions (as independent variables) became the basis for distinguishing the three clusters. It is worth mentioning that usually objective data are used in most cases, whereas the present study did not ask about the objective income of the participants. To better understand the significance of the income received by the participants, they were asked to provide a subjective assessment of their income. This choice is motivated by the desire to better understand how a person estimates his or her well-being.

The following cluster groups were identified after performing the cluster analysis:

- Cluster 1 ( $\mathrm{N}=661)$. The base of the group consists of those who study (schoolchildren, students) or those who have not yet started working careers (unemployed), whose income is fairly distributed among the three lower and middle-income groups. The relative name of this cluster learning youth - is associated with the socio-demographic characteristics of the dominant group.

- Cluster $2(\mathrm{~N}=403)$. The base of the group consists of low- or middle-educated, low-income, skilled, and unskilled workers, with low labor-market adaptability, uncompetitive wages, and a lack of prospects, most of them young and middle-aged. The relative name of this cluster - precariat - is associated with conceptually the most specific name to the group.

- Cluster $3(\mathrm{~N}=429)$. The base of the group consists of highly-educated, middle- and upper-income, adaptable, working-age citizens. The relative name of this cluster - potential - is associated with the significant discursive notion that the departure of this group interprets as a drain on the nation's potential.

The survey reaffirmed that the majority of Lithuanian emigrants are youngsters under 35 years old. The detailed distribution of the respondents among clusters by age is shown in Figure 2 .

The notable differences among clusters are that in the case of the learning youth (cluster 1) the first two dominating age categories are 18-25 (24.5 percent) and 26-35 (45.5 percent), while in the case of the potential (cluster 3 ) the 


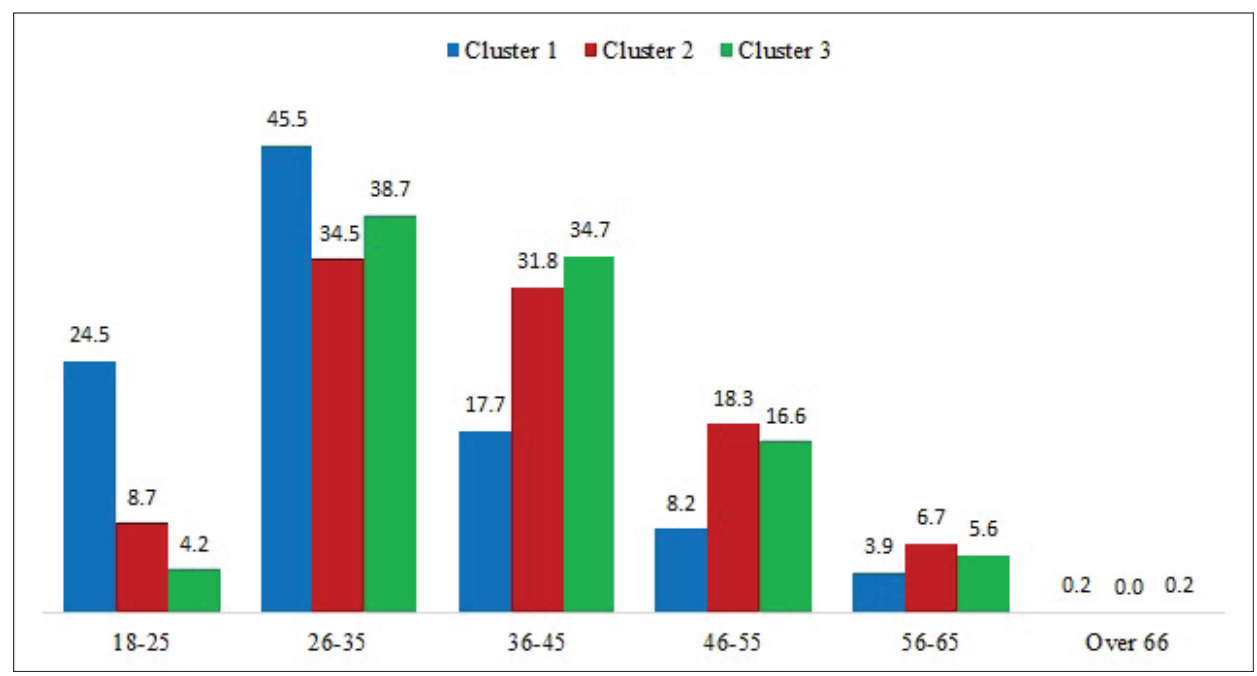

Figure 2. Distribution of respondents by age by clusters $(N=1493)$.

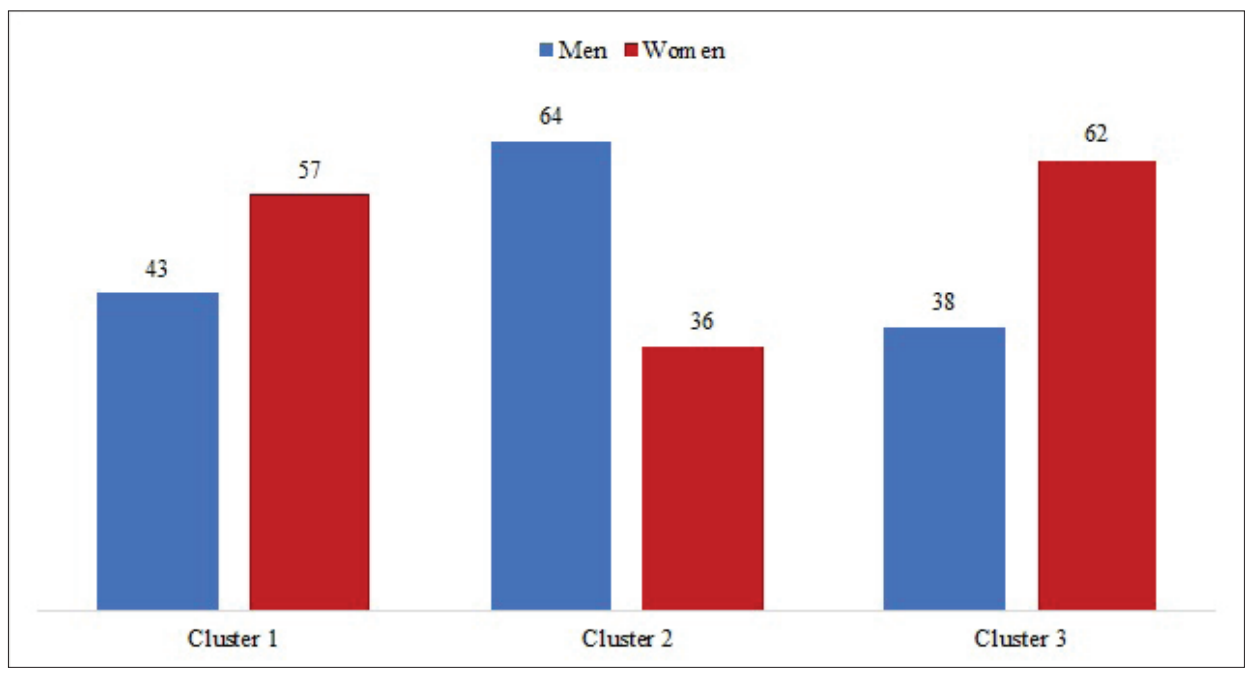

Figure 3. Distribution of respondents by gender by clusters $(N=1493)$.

dominating age categories are the second - 26-35 (38.7 percent) and the third (34.7 percent). In the case of the precariat (cluster 2 ), the distribution is more or less consistent, with a decrease of the group as the age increases.

The distribution of respondents by gender (Fig. 3) revealed that females dominate in both the learning youth and the potential group, but in the case of the precariat, the dominating group is male. 


\section{SOURCES OF EMOTIONAL STATE: GOVERNMENTAL SERVICES VS. PUBLIC ENGAGEMENT}

This section addresses the second objective of the empirical research, by analyzing whether, to what extent, and how the respondents' emotional state depends on their personal involvement and active participation in the creation of the well-being of public life, and to what extent it derives from the expectations delegated to the government and the latter's inability to fulfill them.

The general tendencies of the research revealed that the number of those delegating responsibility for the well-being of public life to the government was significantly higher ( 48.1 percent) than of those who think that it is the responsibility of the society itself (30.4 percent).

The cluster analysis revealed quite significant differences between the attitudes of the learning youth, precariat, and potential respondents (Fig. 4). The percentage of those who associated the creation of the well-being of public life with the government was the highest (58.3 percent) among the precariat (cluster 2), and the lowest (35.4 percent) among the potential (cluster 3 ). The position of the learning youth on this issue is similar to that of the precariat: 50.4 percent of the learning youth chose the answer that the government should ensure the well-being of public life. The differences allow us to consider the contribution of the Lithuanian education system, especially the differences between higher education and vocational training, in shaping the civic responsibility of the younger generation. The percentage of those who perceived the importance of the society in generating the well-being of public life was the highest among the potential respondents (42 percent), whereas in the case of the learning youth it was 27.5 percent and in the case of the precariat 22.1 percent. Thus, only the potential respondents were aware of their civic responsibilities, whereas the representatives of the other two clusters tended to delegate it to the government.

Trust and willingness to cooperate are some of the indicators of social capital in society. The cluster analysis revealed (Fig. 5) that the percentage of people who chose the answer 'I trust people and I think that people who collaborate could do more' was the highest among the potential respondents -50.8 percent, and the lowest in the case of the precariat -37.7 percent. The percentage of those who chose the answer 'I do not trust people, and I think that if you want something to be done right you've got to do it yourself' was the highest (39 percent) among the precariat (cluster 2). A significantly lower percentage (27.3 percent) is seen in the case of the potential respondents. More than 20 percent of the respondents of all the clusters did not have a clear opinion on this issue. 


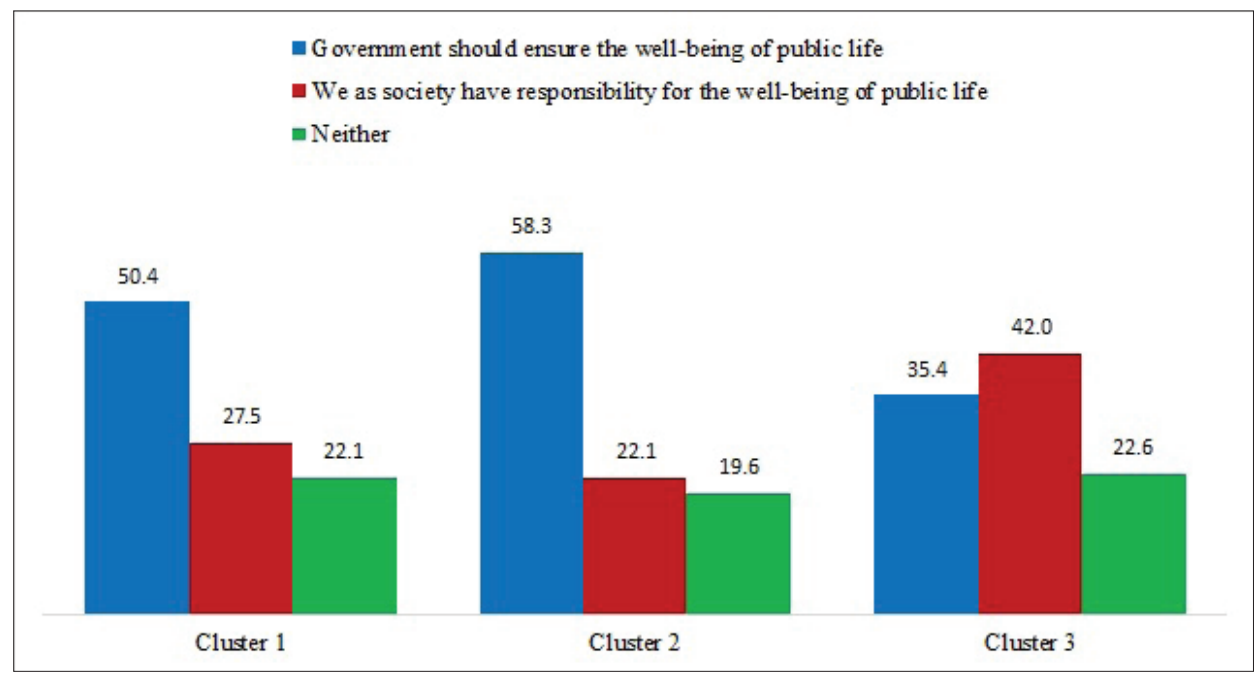

Figure 4. Distribution of respondents by priorities towards responsibilities for the well-being of public life (the role of government vs. society) by clusters ( $N=1493)$.

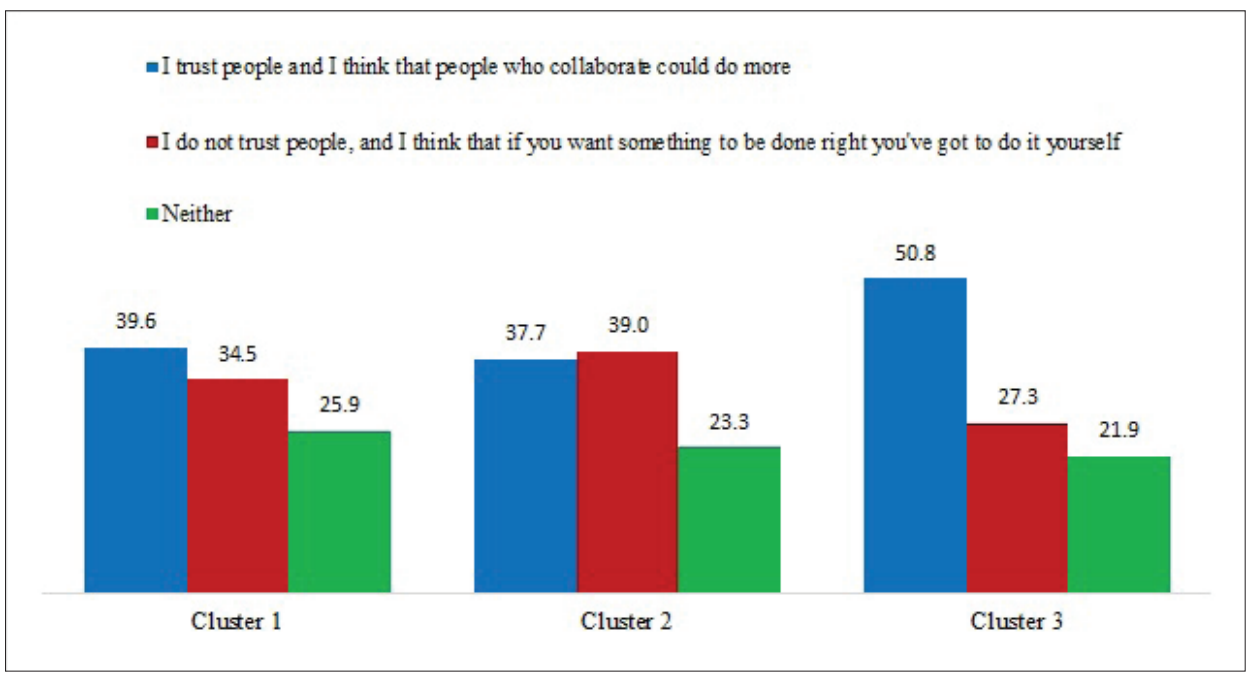

Figure 5. Distribution of respondents by trust by clusters ( $N=1493)$. 
An interesting tendency has emerged: a large proportion of research participants (especially of the learning youth and the precariat) do not perceive themselves as creators of the well-being of public life, and delegate this function to the government. Accordingly, this fosters a dilemma for the government - to position itself as a service provider or to create better opportunities for public involvement. The first is easily achieved but leads to populism or bureaucratization, while the second requires strategic thinking and flexibility but leads to the consistency of the emotional state of the public. Having in mind that more than one-third of the respondents (in the case of all clusters) are reluctant to collaborate on public goals pushes the government for the first avenue. Such attitudes lead to the formation of a binary relationship between the individual and the government, while the third party (various civic associations) is programmed to play the role of an underdog, being able to perform neither decent communication nor representation of the interests of the society.

To find out the distribution of civic engagement among clusters, the survey included questions about participation in civic associations/organizations and initiatives, elections as well as professional and leisure associations (Fig. 6).

The general tendency of the survey showed that 49.7 percent of the respondents participated in the elections (presidential, parliamentary, European parliamentary, municipal, etc.) very often or often. The cluster data analysis revealed differences between groups. Respondents from cluster 3 (potential) were the most active in the elections (69.5 percent), while the representatives of cluster 1 (learning youth) were the least active (40.4 percent). Cluster 2 was not much different from the latter -43.7 percent of its representatives participated very often or often. The number of non-voters was the lowest among the potential (7.5 percent), and the highest among the learning youth -32.8 percent (cluster 1). ${ }^{1}$

Respondents' participation in various civic activities (environmental actions, community activities, public organizations, donations) (Fig. 7) showed a tendency that quite a large proportion (from 42.7 percent to 47.1 percent) of the representatives of all clusters participate in civic activities rarely, that is, non-systematically. 34.7 percent of the overall number of respondents never participated in civic activities.

This option was the least likely to be chosen by the potential (23.5 percent); the tendency of non-participation in the case of the learning youth and the precariat was similar: in the case of cluster 1 (learning youth) - 39.1 percent of the respondents, and slightly more (39.4 percent) in the case of cluster 2 (precariat).

The cluster analysis revealed differences among clusters. In the case of civic activity, representatives of cluster 3 (potential) were the most active (29.4 percent). The representatives of the learning youth and the precariat were significantly less active -18.2 percent and 16.9 percent, respectively. 


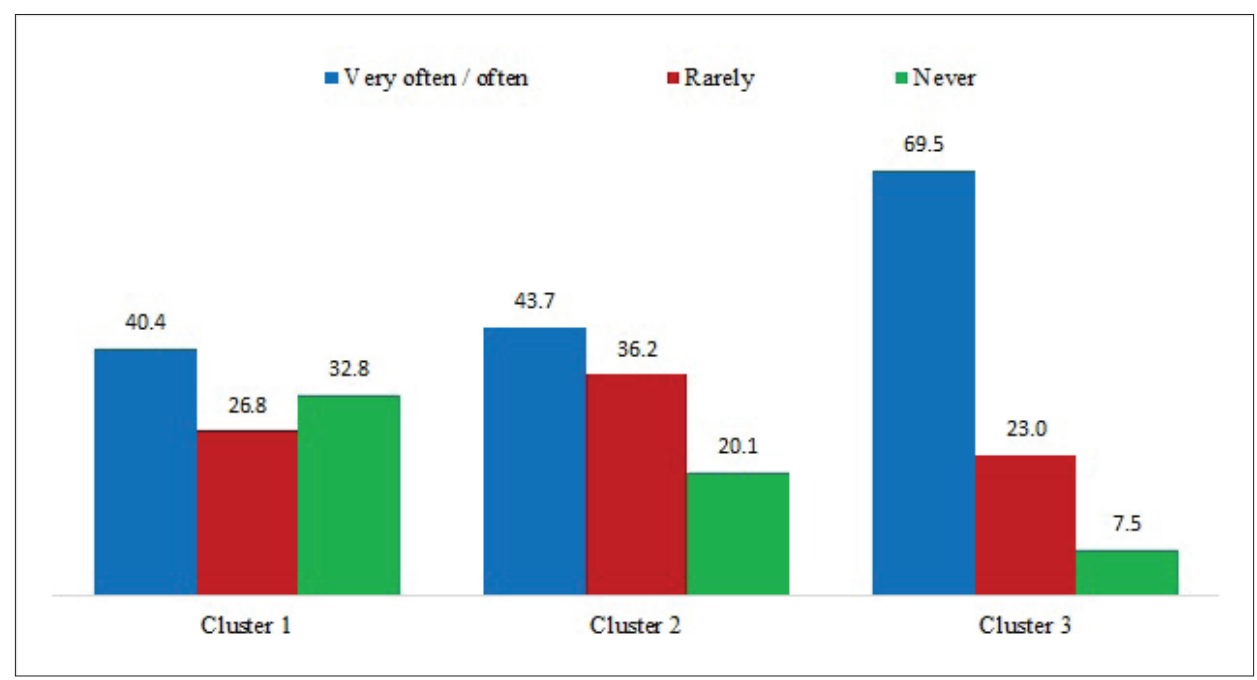

Figure 6. Distribution of respondents by elections turnout by clusters $(N=1493)$.

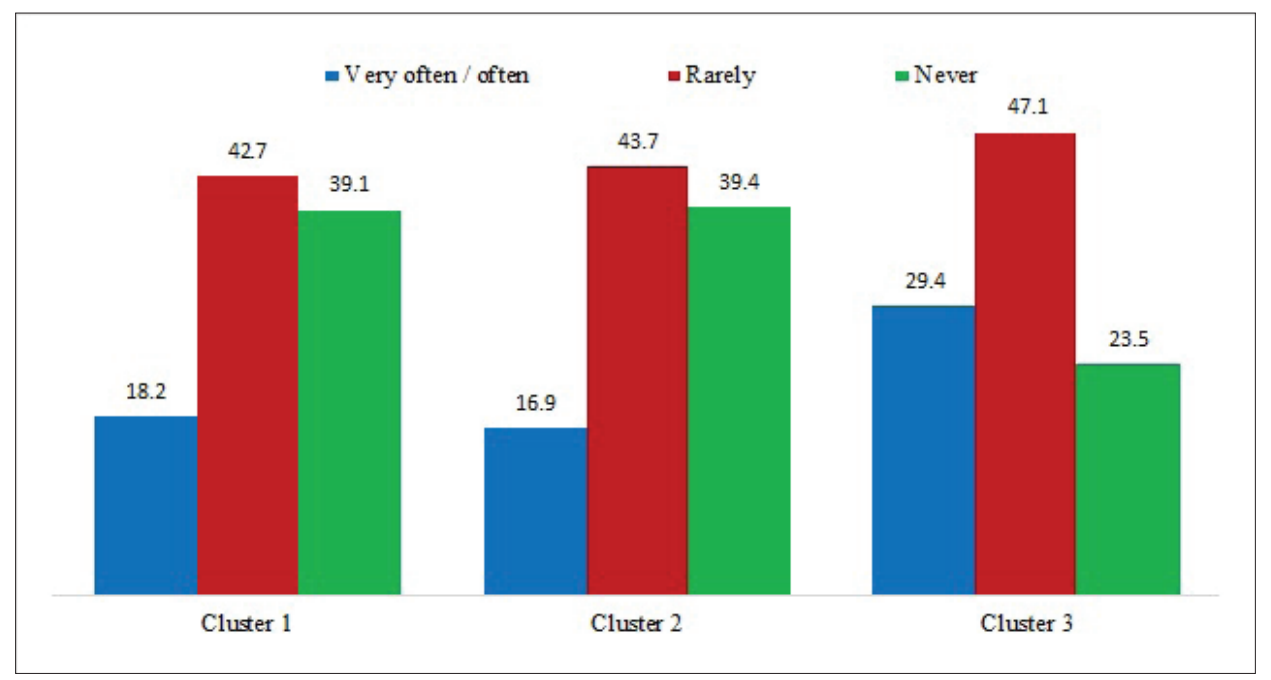

Figure 7. Distribution of respondents by participation in civic activities by clusters $(N=1493)$. 


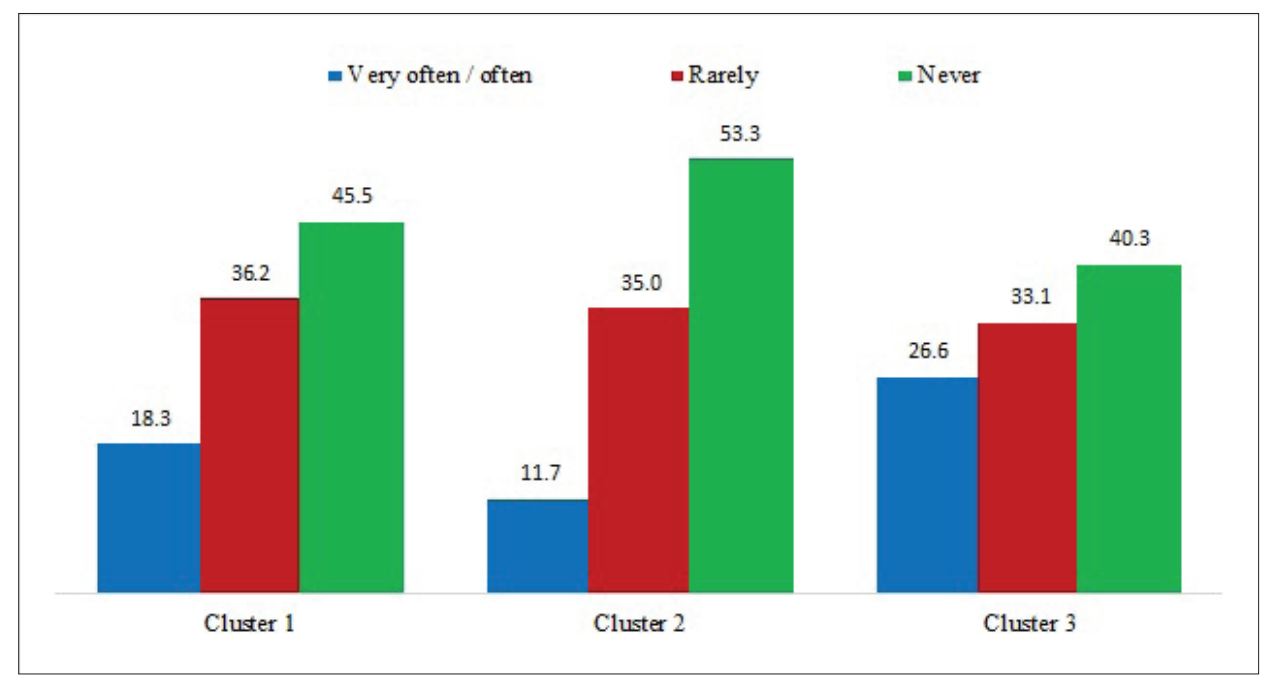

Figure 8. Distribution of respondents by activity in professional and leisure organizations by clusters $(N=1493)$.

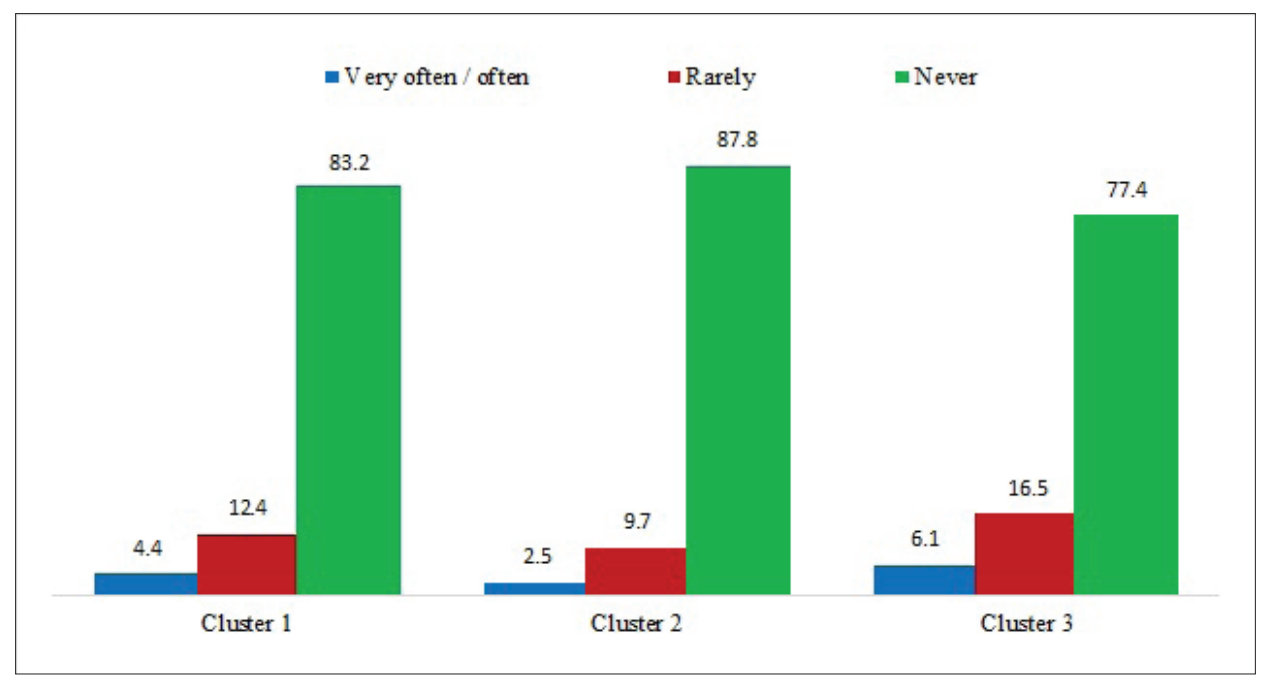

Figure 9. Distribution of respondents by organizing civic activities by clusters $(N=1493)$. 
The survey measured the involvement and distribution of respondents in various professional and leisure organizations (Fig. 8). Here, too, the representatives of the potential (cluster 3 ) showed the greatest activity (26.6 percent - very often / often). The learning youth were more passive (18.3 percent), and the least likely to join a professional or leisure organization were the representatives of the precariat (cluster 2) - only 11.7 percent.

It should be noted that a large proportion of all cluster representatives have never participated in this type of social activity. In the context of clusters, the percentage of those who have never participated in professional and hobby organizations is the highest (53.3 percent) among the respondents of cluster 2 (precariat), and the lowest (40.3\%) among the respondents of cluster 3 (potential).

The study covered not only the frequency but also the depth of civic participation practices (Fig. 9).

The respondents were asked whether they had organized various civic activities themselves (initiated petitions or public projects, appealed to the authorities, organized protests, etc.); the majority of respondents replied they had done none of these. The majority of respondents who chose this answer were among the precariat (cluster $2-87.8$ percent). This percentage was the lowest among the potential respondents (cluster $3-77.4$ percent), whereas in cluster 1 it was 83.2 percent). Very few respondents answered this question positively. Here, too, the most active were the representatives of cluster 3 (potential). 6.1 percent of them organized various civic activities themselves very often or often, and 16.5 percent did it sometimes. The respondents in cluster 2 (precariat) showed the poorest results - only 2.5 percent did it very often or often, and 9.7 percent of them did it sometimes.

To summarize the distribution of respondents according to generalized trust by attitudes and expectations for the government and subjective experiences, individual participation in civic activities can be distinguished by the following characteristics of each cluster:

- Cluster 1 (learning youth). A greater proportion (50.4 percent) of this cluster was inclined to delegate responsibility for the creation of the well-being of public life to the government; this group was more likely (39.6 percent) to trust other people and cooperate for the common interest. In the context of all clusters, it has the lowest rate (40.4 percent) of participation in elections, as well as passive involvement (18.2 percent) in other civic activities. At the time of departure, they had the least contact with the Lithuanian government and indicated the lowest rate (38.1 percent) of having experienced personal disrespect from the 
Lithuanian authorities. As compared to other clusters, the Lithuanian government was criticized the least by this cluster. A significant number of people did not rule out the possibility of returning to Lithuania in the future, but the majority (42.4 percent) saw the real changes in Lithuanian economy and governance as a prerogative of the government. Only less than one-fifth (19.7 percent) of the representatives of this cluster expressed a personal desire to contribute to the creation of a better Lithuania.

- Cluster 2 (precariat). In the context of all clusters, this group delegated the well-being of public life to the government the most (58.3 percent), and was the most mistrustful (39 percent) of other people and unwilling to cooperate in pursuit of common goals. The rate of participation in elections (43.7 percent) was higher than that in cluster 1 but significantly lower than that in cluster 3 . Other civic activities were characterized by non-systematic participation (16.9 percent) or nonparticipation (39.5 percent). Naturally, having the highest expectations for the government, the representatives of this group were also the most dissatisfied with it. The group frequently (48.9 percent) experienced personal disrespect from the authorities. It had the highest percentage (56.8 percent) of those who would consider return to Lithuania if economic and governance problems in Lithuania were solved, but the lowest percentage (17.9 percent) of those who wanted to contribute to the future of a better Lithuania personally.

- Cluster 3 (potential). It is the most civic-conscious (42 percent), most trusting (50.8 percent), and most active (69.5 percent) group. More than the representatives of other clusters, they identified and articulated the main problems related to the Lithuanian government and public services, but were less critical towards the government, even though a large proportion (47.1 percent) of the representatives indicated they had personally experienced disrespect from the authorities or officials. As compared to other clusters, this group had the largest proportion of those who would like to contribute to the welfare of Lithuania upon return, and the smallest proportion of those who considered it to be a matter of the government. 


\section{EMOTIONAL INEQUALITY AMONG THE CLUSTERS}

After investigating the relations between the emotional state and its formation contexts (the contexts of interactions), this section will address the third task of empirical research - to empirically describe the distribution of emotional inequality among clusters.

Table 1. Emotional state while living in Lithuania: distribution of happiness vs. unhappiness among clusters.

\begin{tabular}{|l|c|c|c|}
\hline \multirow{2}{*}{$\begin{array}{l}\text { How would you describe your } \\
\text { emotional state while living }\end{array}$} & \multicolumn{3}{|c|}{ Cluster number } \\
\cline { 2 - 4 } in Lithuania? & 1 & 2 & 3 \\
\hline I was happy and felt sad I had to leave & $28.3 \%$ & $32.5 \%$ & $33.6 \%$ \\
\hline $\begin{array}{l}\text { I was unhappy and I felt glad I could } \\
\text { leave }\end{array}$ & $34.2 \%$ & $40.2 \%$ & $24.9 \%$ \\
\hline Neither of those & $37.5 \%$ & $27.3 \%$ & $41.5 \%$ \\
\hline Total & $100.0 \%$ & $100.0 \%$ & $100.0 \%$ \\
\hline
\end{tabular}

The general results of the survey demonstrate a rather poor emotional state of society. Only about one-third of society was happy in their homeland and, unfortunately, far more were unhappy, and emigration was associated with joy. The distribution of emotional inequality among groups is also quite notable. Even in the best (potential) case, only 33.6 percent were able to feel happy. Meanwhile, in the case of the precariat, the unhappiness rate was higher -40.2 percent. It is worth mentioning that among all the clusters there was a relatively high proportion of those who were undecided.

Table 2. Emotional state while living in Lithuania: distribution of work vs. income satisfaction among clusters.

\begin{tabular}{|l|c|c|c|}
\hline \multirow{2}{*}{$\begin{array}{l}\text { How would you describe your } \\
\text { emotional state while living } \\
\text { in Lithuania? }\end{array}$} & 1 & 2 & 3 \\
\cline { 2 - 4 } & $26.6 \%$ & $56.8 \%$ & $47.8 \%$ \\
\hline $\begin{array}{l}\text { I was satisfied with my work in } \\
\text { Lithuania, except for my income }\end{array}$ & $14.8 \%$ & $16.4 \%$ & $20.5 \%$ \\
\hline $\begin{array}{l}\text { Not the income, but the attitude of } \\
\text { the employers towards the employee } \\
\text { annoyed me the most }\end{array}$ & $58.5 \%$ & $26.8 \%$ & $31.7 \%$ \\
\hline Neither of those & $100.0 \%$ & $100.0 \%$ & $100.0 \%$ \\
\hline Total & &
\end{tabular}


The precariat associates emotional (dis)satisfaction with work and income (56.8 percent). This is quite logical, given the constant challenge this group faces to adapt to the labor market. Thus emotional dissatisfaction is associated with the most actual (employment) problem. The indecisiveness of cluster 1 (58.5 percent) is understandable, as most of them had no work experience before departure. Interestingly, the emotional well-being of the potential is also strongly related to the work context (47.8 percent); although, as predicted, a higher proportion (20.5 percent) attributes dissatisfaction not to income but relationships between employers and employees.

Table 3. Emotional state while living in Lithuania: distribution of society vs. governance satisfaction among clusters.

\begin{tabular}{|l|c|c|c|}
\hline \multirow{2}{*}{$\begin{array}{l}\text { How would you describe your } \\
\text { emotional state while living }\end{array}$} & \multicolumn{2}{|c|}{ Cluster number } \\
\cline { 2 - 4 } in Lithuania? & 1 & 2 & 3 \\
\hline $\begin{array}{l}\text { I was satisfied with the Lithuanian way } \\
\text { of life and our society in general, but I } \\
\text { did not like the country's governance }\end{array}$ & $45.4 \%$ & $59.3 \%$ & $50.3 \%$ \\
\hline $\begin{array}{l}\text { I was satisfied with the governance of } \\
\text { the country but not with society and its } \\
\text { habits }\end{array}$ & $7.9 \%$ & $4.5 \%$ & $9.1 \%$ \\
\hline Neither of those & $46.7 \%$ & $36.2 \%$ & $40.6 \%$ \\
\hline Total & $100.0 \%$ & $100.0 \%$ & $100.0 \%$ \\
\hline
\end{tabular}

The data once again confirm the assumption that the poor emotional state of society results not so much from interactions among different social groups (though this aspect remains relevant and needs to be further explored in future research) but from country's governance (institutions vs. the public). The high percentage of those who were undecided leaves quite a few interpretations, especially given the relatively low civic activism among all groups and the high level of mistrust. In both the precariat and the potential cases, emotional satisfaction with society exceeds the threshold of 50 percent.

Table 4. Emotional state while living in Lithuania: distribution of satisfaction of personal belonging among clusters.

\begin{tabular}{|l|c|c|c|}
\hline \multirow{2}{*}{$\begin{array}{l}\text { How would you describe your } \\
\text { emotional state while living } \\
\text { in Lithuania? }\end{array}$} & \multicolumn{3}{|c|}{ Cluster number } \\
\cline { 2 - 4 } & 1 & 2 & 3 \\
\hline I felt needed in Lithuania & $13.2 \%$ & $12.4 \%$ & $25.4 \%$ \\
\hline I felt superfluous in Lithuania & $59.5 \%$ & $63.0 \%$ & $47.3 \%$ \\
\hline Neither of those & $27.4 \%$ & $24.6 \%$ & $27.3 \%$ \\
\hline Total & $100.0 \%$ & $100.0 \%$ & $100.0 \%$ \\
\hline
\end{tabular}


The final question measures the respondents' subjective satisfaction with their personal belonging to society. The answers reveal the respondents' attitudes towards the country, the society, and their perception of themselves (their position) in the country. As can be seen above, the distribution of responses among the clusters and the general tendency of all the clusters is shocking. Even in the best case (potential), only a quarter (25.4 percent) felt needed in their homeland.

Meanwhile, in both other cases - 13.2 percent of the learning youth and 12.4 percent of the precariat - the situation is alarming. On the other hand, this partly explains the general trends in the popularity of emigration and the rather negative attitude of emigrants to their homeland even after emigration. Further research should elaborate on the issue and delve into the specific contexts of these experiences, and concretize the definition as well as interpretation of the feeling itself. Be that as it may, even the abstract question (or rather the answers of the respondents) eloquently reveals a highly critical self-reflection of personal belonging to society.

When summarizing these results in the context of the main distinguishing features of each cluster, few insights can be offered. A deep internalization of low self-esteem or even an inferiority complex is seen among all clusters (but mostly in the precariat) as if the individual (and especially the less fortunate in life) has little meaning in the country. It seems that those who need love and tenderness the most experience it the least. People who cannot express themselves positively lack the means to become socially acceptable. This is how a closed circle is formed when communication leads to the avoidance of social contact because of the personal shortcomings and failures in interactions with others (Charlesworth 2000). People who perceive themselves negatively push themselves into a lower social position where their opportunities become limited. Thus, people feel lost in the symbolic struggle for recognition (Bourdieu 2000: 242 ), which in this case becomes an important reason to leave their homeland.

Emotional inequality among clusters seems to correlate with the previous results: the distribution of civic passivity, tendencies for shallow involvement in the creation of the well-being of public life, and the creation of constant expectations for the government. The data show that the precariat is experiencing the greatest emotional deprivation. Meanwhile, we see a much different tendency in the case of the potential cluster - being more active, more critical of themselves, and the government (in terms of expectations) but more confident, they live in a better (albeit slightly) emotional context. The situation of the learning youth is yet somehow different, and their emotional state is not good either, and in many cases (for example, happiness, satisfaction with society, or even a sense of belonging to society) it is worse, but in many respects the cluster expressed strong undecidedness. This fosters the assumption that perhaps, by associating 
their future with another country, the members of this cluster do not identify the emotional state with the circumstances and interactions in Lithuania.

\section{CONCLUSIONS}

Weak civic engagement, mainly focusing on participating in elections, is seen among all clusters. Meanwhile, the forms of activity representing deeper involvement in the creation of the public good received respondents' significantly lower involvement. The results suggest that a vast majority of respondents perceive themselves neither as creators of the public good nor as contributors of the country's well-being, and can be described as users of social products created by other initiators (including state institutions). Only representatives of the potential (cluster 3 ) tried to contribute in somewhat larger proportions, which indicates their better self-perception as the creators of the public good and contributors to the country's well-being. Accordingly, their emotional state is slightly better and more consistent. The representatives of the other two clusters (learning youth and precariat) are not only inclined to delegate their civic responsibilities to the government and distance themselves from more active involvement in the creation of the public well-being, but to blame others for their poor emotional climate. For example, the representatives of cluster 2 (precariat) and cluster 1 (learning youth) expect much from the government, but at the same time do not engage in civic activities, do not ensure proper representation of their interests nor communicate their needs, thus getting themselves into the limited experience with poor emotional climate. Unfulfilled expectations result in associating their poor emotional experience with the 'bad' government.

The poor emotional state of emigrating Lithuanians is formed by several intertwined factors: 1) personal experience while living in Lithuania and in the emigration country allows to compare both the relations of the government and the public, and the efficiency as well as empathy of public services for ordinary citizens; 2) the poor baggage of emotional experiences (pre-departure) and the tendency to generalize negative attitudes both in relation to the government and citizens as well as between different social groups; 3) the existence of inertial attitudes in society, such as delegating responsibility for the well-being of public life to the government and being in a state of a priori constant dissatisfaction, as well as detachment from individual contribution for public well-being (activities that potentially might change the situation), allow the prevalence of the hermetic states of individual satisfaction with their powerlessness. 


\section{NOTES}

1 For comparison, in 2014, in the second round of the presidential election, 47.37 percent of the overall number of Lithuanians participated; in municipal elections in 2015-38.73 percent, and in the parliamentary elections in $2016-50.61$ percent. Thus, it becomes clear that the activity of the representatives of cluster 1 and cluster 2 corresponds to the general voting tendencies in Lithuania, while the representatives of cluster 3 outperform them (see https://www.vrk.lt/statiniai/puslapiai/2014_prezidento_rinkimai/ output_lt/rinkimu_diena/rezultatai_isankstiniai2.html; https://www.vrk.lt/2016seimo/rezultatai?srcUrl=/rinkimai/102/1/1304/rezultatai/lt/rezultataiSuvestine1.html, both last accessed on 14 January 2020).

\section{REFERENCES}

Aleksandravičius, Egidijus 2019. Amžiaus slenksčiai. [Thresholds of the Century.] Vilnius: Versus Aureus.

Bericat, Eduardo 2016. The Sociology of Emotions: Four Decades of Progress. Current Sociology, Vol. 64, No. 3, pp. 491-513. http://dx.doi.org/10.1177/0011392115588355.

Bermeo, Nancy \& Nord, Philip 2000. Civil Society Before Democracy: Lessons from Nineteenth-Century Europe. Lanham \& Boulder \& New York \& Oxford: Rowman and Littlefield Publishers Inc.

Bleizgienè, Ramunè 2015. Emocijų istorijos tyrimu kelias: Peterio ir Carol Stearnsų, Barbaros Rosenwein ir Williamo Reddy teoriniai modeliai. [Studying the History of Emotions: The Theories of Peter and Carol Stearns, Barbara Rosenwein, and William Reddy.] Colloquia, Vol. 34, pp. 13-36. Available at https://www.academia. edu/19558503/, last accessed on 14 January 2020.

Bourdieu, Pierre et al. (eds.) 1999. The Weight of the World: Social Suffering in Contemporary Society. Stanford: Stanford University Press.

Bourdieu, Pierre 2000. Pascalian Meditations. Transl. by R. Nice. Cambridge: Polity Press.

Charlesworth, Simon J. 2000. A Phenomenology of Working Class Experience. Cambridge: Cambridge University Press. https://doi.org/10.1017/CBO9780511489419.

Civic Power 2016 = Pilietinès galios indeksas 2016. [Civic Empowerment Index 2016.] Available at http://www.civitas.lt/time-line/pilietines-galios-indeksas-2016-m/, last accessed on 14 January 2020.

Emigration issues 2006 = Emigracija iš Lietuvos: padetis, problemos, galimi sprendimo būdai. [Emigration from Lithuania: Situation, Problems, and Possible Solutions.] Konferencijos medžiaga. Vilnius: Valstybès žinios. Available at http://www3.lrs. lt/docs2/TKAKCQXM.PDF, last accessed on 14 January 2020.

Gaidytè, Teodora 2013. Trust in Mature and Post-Communist Democracies. Sociopedia. isa. DOI: $10.1177 / 205684601364$. 
Ganzeboom, Harry B.G. \& De Graaf, Paul M. \& Treiman, Donald J. 1992. A Standard International Socio-economic Index of Occupational Status. Social Science Research, Vol. 21, No. 1. pp. 1-56. http://dx.doi.org/10.1016/0049-089X(92)90017-B.

Genelytè, Indrè 2019. (Ine)quality of Life: Lithuanian Labor Migration to Sweden During the Economic Crisis and Its Aftermath, 2008-2013. Journal of Baltic Studies, Vol. 50, No. 1, pp. 79-104. https://doi.org/10.1080/01629778.2019.1570286.

Genys, Dainius 2018. The Power of Lithuanian Civil Society and Its Boundaries. In: David Horton Smith \& Alisa Moldavanova \& Svitlana Krasynska (eds.) The Nonprofit Sector in Eastern Europe, Russia, and Central Asia: Civil Society Advances and Challenges. Leiden, Netherlands \& Boston, MA: Brill Publishers, pp. 223-242. https://doi.org/10.1163/9789004380622_012.

Genys, Dainius 2019. Emocijų kartografija: Subjektyvios lietuvių emigrantų patirtys. [Map of Emotions: The Subjective Experiences of Emigrants.] OIKOS: lietuviu migracijos ir diasporos studijos [Oikos: Lithuanian Diaspora and Migration Studies], Vol. 1, No. 27, pp. 45-59. https://doi.org/10.7220/2351-6561.27.2.

Genys, Dainius \& Krikštolaitis, Ričardas 2018. Išvykusių lietuvių požiūrio į Lietuvą skirtumai. [Looking for Differences: Changes in the Way Migrants View Lithuania After They Have Left It.] OIKOS: lietuviu migracijos ir diasporos studijos [Oikos: Lithuanian Diaspora and Migration Studies], Vol. 1, No. 25, pp. 7-24. https:// doi.org/10.7220/2351-6561.25.1.

Gregg, Samuel 2018. Katalikybè ir laisvè: argumentai už apribota valdžia, laisva ekonomika ir religijos laisvę. [Catholicism and Freedom: Arguments for Restricted Power, Free Economy, and Religious Freedom.] Vilnius: Aštuntoji diena.

Howard, Marc Morjé 2003. The Weakness of Civil Society in Post-Communist Europe. Cambridge: Cambridge University Press.

Kraus, Michael 2017. The Roles of Emotions in Social Hierarchies. Emotionresearcher. com. Available at http://emotionresearcher.com/the-roles-of-emotions-in-socialhierarchies/, last accessed on 15 January 2020.

Laurinavičius, Antanas \& Laurinavičius, Algimantas 2017. Emigration: A Price of Inequality or a Breach of Social Contract? In: Contemporary Issues in Business, Management and Education. Vilnius: Technika, pp. 1-8. https://doi.org/10.3846/ cbme.2017.018.

Lively, Kathryn J. 2017. The Sociology of Emotion: Emotion as Both Social Object and Social Force. Emotionresearcher.com. Available at http://emotionresearcher. com/the-sociology-of-emotion-emotion-as-both-social-object-and-social-force/, last accessed on 15 January 2020.

Müller, Karel B. 2006. The Civil Society-State Relationship in Contemporary Discourse: A Complementary Account from Giddens' Perspective. The British Journal of Politics \& International Relations, Vol. 8, No. 2, pp. 311-330. http://dx.doi. org/10.1111/j.1467-856x.2006.00212.x.

Noreika, Alvydas 2016. Kultūra ir emocijos Vytauto Kavolio sociologijoje. [Culture and Emotions in Vytautas Kavolis' Sociology.] Vilnius: Lietuvos kultūros tyrimų institutas. 
Servetkienè, Vaida 2012. Gyvenimo kokybė Lietuvoje: subjektyvus situacijos vertinimas ir realybė. [The Quality of Life in Lithuania: Subjective Assessment of the Situation and Reality.] Ekonomika ir vadyba: aktualijos ir perspektyvos [Economics and Management: Current Issues and Perspectives], Vol. 4, No. 28, pp. 20-35. Available at http://www.su.lt/bylos/mokslo_leidiniai/ekonomika/2012_4_28/servetkiene.pdf, last accessed on 15 January 2020.

Spurga, Saulius 2008. Komunistinis įspaudas Vidurio Rytų Europos valstybiu pilietinejje visuomeneje. [The Communist Imprint on the Civil Society of Central and Eastern European States.] Darbai ir Dienos [Deeds and Days], No. 49, pp. 235-249. Available at https://www.vdu.lt/cris/bitstream/20.500.12259/32633/1/ISSN23358769_2008_N_49.PG_235-249.pdf, last accessed on 15 January 2020.

Statistical data 2018 = Migracija Skaičiais. [Migration in Numbers 2018.] Available at http://123.emn.lt/\#emigracija, last accessed on 15 January 2020.

Statistical data 2019 = Migracijos ir gyventoju migrantu statistika. [Migration and Migration Population Statistics 2019.] Available at: http://ec.europa.eu/eurostat/ statistics-explained/index.php/Migration_and_migrant_population_statistics/lt, last accessed on 15 January 2020.

Stets, Jan E. \& Turner, Jonathan H. (eds.) 2006. Handbook of the Sociology of Emotions. New York: Springer.

Tereškinas, Artūras 2014. Permąstant socialinę atskirtị ir socialinį kentèjimą. [Rethinking Social Exclusion and Social Suffering.] Kultūra ir visuomenè. Socialiniu tyrimu žurnalas [Culture and Society: Journal of Social Research], Vol. 5, No. 3, pp. 153169. http://dx.doi.org/10.7220/2335-8777.5.3.9.

Tereškinas, Artūras \& Žilys, Apolonijus 2013. Emocijos ir socioerdvinė segregacija Lietuvos didmiesčiuose: ar aš galiu ką nors pakeisti? [Emotions and Socio-Spatial Segregation in Lithuanian Cities: Am I Powerful Enough to Influence Change?] Kultūra ir visuomenè: Socialiniu tyrimu žurnalas [Culture and Society: Journal of Social Research], Vol. 4, No. 2, pp. 11-35. Available at https://www.vdu.lt/cris/ bitstream/20.500.12259/31857/1/ISSN2335-8777_2013_N_4_2.PG_11-35.pdf, last accessed on 15 January 2020.

Thoits, Peggy A. 1989. The Sociology of Emotions. Annual Review of Sociology, Vol. 15, pp. 317-342. http://dx.doi.org/10.1146/annurev.so.15.080189.001533.

Turner, Jonathan H. 2000. On the Origins of Human Emotions: A Sociological Inquiry into the Evolution of Human Effect. Stanford, CA: Stanford University Press.

Turner, Jonathan H. 2009. The Sociology of Emotions: Basic Theoretical Arguments. Emotion Review, Vol. 1, No. 4, pp. 340-354. https://doi.org/10.1177\%2F1754073909338305.

Woolfson, Charles \& Juska, Arunas \& Genelyte, Indrè 2012. Crisis, Social Trust and Migratory Exit from Lithuania. Paper at the 26th Conference of the Nordic Sociological Association, "Trust and Social Change", 17 August 2012, University of Iceland, Reykjavik. Available at https://notendur.hi.is/shj/Papers/Trust.and. Social.capital/Crisis\%20trust\%20and\%20migration\%20from\%20Lithuiania\%20 NSA\%20paper\%208\%20August\%202012.docx, last accessed 14 June 2019. 
Dainius Genys (PhD) is researcher at Andrei Sakharov Research Centre for Democratic Development at Vytautas Magnus University, Lithuania. His main research areas are democratization processes and migration studies.

dainius.genys@vdu.lt

Ilona Strumickiene $(\mathrm{PhD})$ is chief methodologist-researcher at Adolfas Damušis Democratic Studies Centre at Martynas Mažvydas National Library of Lithuania. Her main research areas are the history of Lithuanian diaspora, return migration and its impacts on Lithuanian society.

ilona.strumickiene@lnb.lt

Ričardas Krikštolaitis $(\mathrm{PhD})$ is professor at the Department of Mathematics and Statistics at Vytautas Magnus University, Lithuania. His main research areas are risk and reliability analysis, energy security, and statistical data analysis.

ricardas.krikstolaitis@vdu.lt 